\title{
Afrikaans-moedertaalonderrig onder beleg
}

\author{
Johan Lubbe \\ Eenheid vir Taalbestuur, Universiteit van die Vrystaat, Bloemfontein, 9300. \\ E-pos: evtb@mail.uovs.ac.za
}

\section{Inleiding}

Die Grondwet van die Republiek van Suid-Afrika (Wet no 108 van 1996) erken nie alleen 11 tale as amptelik nie, maar verklaar dat elke leerder die reg het tot onderrig in die taal van keuse. Een van die moontlikhede wat uitgesonder word om hierdie reg te implementeer is die instelling van enkelmediumskole. In die praktyk skyn dit egter of die owerhede spesifiek Afrikaans-enkelmediumskole en -opvoedkundige inrigtings teiken om óf dubbel- óf parallelmediuminrigtings te word. Aan die hand van amptelike stappe wat deur die onderwysowerhede in drie provinsies teen Afrikaans-enkelmediumskole geneem is en wat tot litigasie gelei het, sal in die volgende afdelings (i) die belang van moedertaalonderrig en (ii) die reg tot moedertaalonderrig teenoor die reg om onderrig in die taal van keuse te ontvang, aan die bod kom. Die gevolgtrekking is dat daar genoegsame getuienis is dat Afrikaansmoedertaalonderrig in enkelmediumskole werklik in 'n staat van beleg verkeer.

\section{Belang van moedertaalonderrig}

Die term "moedertaal", soos baie ander terme wat in taalbeplanning ter sprake is, is 'n ideologies gelaaide term (Phillipson 1992:39 e.v.). Spesifiek in Suid-Afrika is die begrip weens redes wat later bespreek sal word - sterk gestigmatiseer. Kriteria deur Phillipson (1992:39) aangelê vir die bepaling van 'n moedertaal is oorsprong, funksies, bedrewenheid, vereenselwiging en identifikasie deur ander, asook of dit die taal van (een van) die biologiese 
ouer(s) is. Waar dit verder gebruik word, word dit aangewend in die betekenis wat UNESCO daaraan heg as

the language which a person has acquired in early years and which normally has become his natural instrument of thought and communication (soos aangehaal deur Kamwangamalu 2004:226).

Webb (2006) bespreek opvoedkundige, politieke, en kulturele argumente ter ondersteuning van moedertaalonderrig en ook die ontoepaslikheid van argumente ter ondersteuning van 'n eerste addisionele taal (Engels) as onderrigmedium. Voordele van moedertaalonderrig, veral in die vroeëre stadia, word ook uitgespreek deur onder andere Spolsky (1986), Pattanayak (1988), Cummins (1989), Skutnabb-Kangas (2000), en Bamgbose (2000), en spesifiek in Suid-Afrikaanse omstandighede deur Murray (2002), Heugh (2000, 2002, 2003), en Desai (2003).

Talle empiriese studies ter ondersteuning van moedertaalonderrig is al onderneem. Webb (2006:44) verwys na navorsing wat in onder andere Nigerië, Malawi, Zambië, Peru, Madagaskar, Niger, en die VSA in dié verband onderneem is, terwyl Murray (2002:437-438), Heugh (2000), Bloch (2002), en Plüddemann (2002) na verskeie empiriese ondersoeke in Suid-Afrika verwys waar aangetoon is dat te vroeë uitsluitlike onderrig deur medium Engels lei tot afnemende tweetaligheid, wat op sy beurt tot gevolg het dat 'n groot persentasie SuidAfrikaners se taalvaardighede in sowel hulle moedertaal as 'n tweede dominante taal nie voldoende is vir die doel van formele onderrig en die eise van die moderne arbeidsmark nie.

'n Belangrike rede waarom die voordele van moedertaalonderrig grootliks negeer word en daar gekies word vir onderrig in uitsluitlik Engels, is ideologies van aard. Cobarrubias (1983:63-66) onderskei basies twee taalideologieë, naamlik taalassimilasionisme en taalpluralisme. Onderliggend aan hierdie twee taalideologieë lê twee algemene ideologieë, naamlik homogenisme en nasionalisme. Homogenisme propageer die idee dat 'n enkele identiteitsmerker bevordelik is vir nasiebou. Verskille in 'n gemeenskap word as gevaarlik en middelpuntvliedend beskou. Die ideale gemeenskap is eentalig en mono-etnies. Daar word selfs 'n verband tussen homogenisme en ekonomiese voorspoed gelê (Blommaert en Verschueren 1998:194-195). 
Onderskrywing van die houding dat eentaligheid 'n gemeenskaplike identiteit skep en kan verenig - en meertaligheid daarenteen onderskeid en verdeling - lei tot die beskouing dat meertaligheid 'n probleem is, en nie as 'n hulpbron/bate of as 'n reg beskou word nie (Ruiz 1988). Die oplossing van die probleem lê vir voorstanders van homogenisme in taalassimilasionisme en eentaligheid.

Historiese teenkanting teen apartheid kan in Suid-Afrika as 'n verdere ideologie onderskei word wat die taalhouding van die groot meerderheid sprekers bepaal. Hoewel die hoofoogmerke van spesifiek die Bantoe-onderwyswet no 47 van 1953, en die amendement daarvan (Wet no 90 van 1979), eerstens was om gelykberegtiging tussen Afrikaans en Engels te bewerkstellig deur hulle eweveel as onderrigtale te gebruik, en tweedens om moedertaalonderrig in swart skole uit te brei, het die konsekwensies van die implementering van die beleid verreikende gevolge gehad, waaronder heftige teenstand deur swart leerders en hulle ouers teen sowel Afrikaans as teen moedertaalonderrig (Heugh 2002:450, Reagan 2002:422, Kamwangamalu 2004:228-231, Perry 2004:111-114, Webb 2006:45). Terselfdertyd is die status van Engels in die oë van die swart bevolking verhoog deurdat Engels as bevrydingstaal beskou is. Pogings om inheemse Afrikatale te bevorder, word steeds met agterdog bejeën en as nieu-apartheidstrategieë beskou om nie net wit en swart sprekers te skei nie, maar ook swartes te verdeel (Makoni 1997:15; 2003:140, 142).

Moedertaalonderrig kan teoreties in 'n enkelmediumskool, 'n parallelmediumskool, en selfs tot 'n mate in 'n dubbelmediumskool gevolg word. Is daar egter 'n ongelyke magsverdeling tussen die twee betrokke tale, verswak die posisie van die een taal, en derhalwe is die enkelmediumskool die beste waarborg vir die voortbestaan van 'n betrokke taal. In die res van hierdie artikel word met "moedertaalonderrig" spesifiek onderrig in enkelmediumskole bedoel.

In hierdie lig moet die druk wat die onderskeie onderwysdepartemente op Afrikaansenkelmediumskole uitoefen om van hulle toelatingsbeleid af te sien, beoordeel word. In 1994 was daar bykans 2,200 Afrikaans-mediumskole in Suid-Afrika, teenoor 310 (180 primêr en 130 sekondêr) in 2003 (Van Zyl 2003). Na die opsomming in die volgende afdeling van die amptelike stappe wat teen Afrikaans-enkelmediumskole geneem is en wat tot litigasie gelei 
het, sal in die lig daarvan algemene relevante regsbeginsels, en twee oënskynlik teenoorstaande staatsregterlike beginsels - naamlik aandrang op moedertaalonderrig, teenoor reg tot toegang in taal van keuse (lees Engels) - in die besonder, bespreek word.

\section{Amptelike optrede teen Afrikaans-enkelmediumskole wat tot litigasie gelei het}

Tot Desember 2001 was die Primêre Skool Middelburg (Mpumalanga) 'n Afrikaansenkelmediumskool. Op 28 November 2001, enkele dae voor die sluiting van skole vir die Desembervakansie, is die betrokke skool deur 'n amptenaar van Mpumalanga se Departement van Onderwys aangesê om 20 leerders in te skryf wat van voorneme is om vanaf Januarie 2002 in Engels by die skool onderrig te word. Toe die skool toelating geweier het omdat die skool se onderrigmedium Afrikaans was, is die skool se magtiging om leerders tot die skool toe te laat, op 14 Januarie 2002 teruggetrek. Die volgende dag, 15 Januarie 2002, het 'n amptenaar van die Departement, vergesel van ander departementslede, die LP van die African National Congress (ANC) en verteenwoordigers van die ANC Jeugliga, die Middelburg munisipale raad en die Suid-Afrikaanse Polisiediens, by die skool opgedaag en 8 leerders ingeskryf wat in Engels onderrig sou word.

Sedert 1996 het twee voormalige Afrikaans-mediumskole in dieselfde skooldistrik reeds parallelmediumskole geword en leerders ingeneem wat Engels as onderrigmedium gekies het. Dit het die Primêre Skool Middelburg as die enigste openbare skool in die spesifieke gebied gelaat wat uitsluitlik Afrikaans as onderrigmedium gebruik het. Daar is ook 'n Engelsmediumprimêre skool in dieselfde distrik. By al drie hierdie skole was openinge om kinders te akkommodeer wat verkies het om in Engels onderrig te word.

Die Primêre Skool Middelburg het geweier om 'n dubbelmediumskool te word en by die hof aansoek gedoen om die besluit van die Departement om die skool 'n dubbelmediumskool te verklaar, ter syde te stel. Die saak het in September 2002 in die Transvaalse Provinsiale Afdeling voor regter Bertelsmann gedien (Laerskool Middelburg en 'n ander $v$ Departementshoof: Mpumalanga Departement van Onderwys en andere [2002] 4 AII SA 745(T)).

Soortgelyke druk is deur die Wes-Kaapse Onderwysdepartement uitgeoefen om die Laerskool Mikro in Kuilsrivier te verplig om 'n Engelse baan in te stel. Die skool is in 1972 gestig, en 
sedert 1973 is dit 'n enkelmediumskool met Afrikaans as onderrigtaal. Op 2 Desember 2004, 'n dag voor die skole vir die Desembervakansie sou sluit, is die prinsipaal opdrag gegee om 'n groep leerders in Januarie 2005 toe te laat en aan hulle onderrig in Engels te verskaf. Indien die opdrag nie gehoorsaam word nie, sou daar dissiplinêr teen die prinsipaal opgetree word. Op 19 Januarie, met die heropening van die skole, het twee senior lede van die Onderwysdepartement by die skool opgedaag, en gesorg dat 21 Graad 1-leerders wat verkies het om in Engels onderrig te word, ingeskryf word.

Soos in die Middelburg-geval was hier ook in dieselfde skooldistrik 'n ander parallelmediumskool beskikbaar wat onderrig in sowel Afrikaans as Engels verskaf, en wat die 21 leerders maklik kon akkommodeer.

Ook die Laerskool Mikro was genoop om hom tot die hof te wend met die versoek dat die besluit van die Departement rakende die toelating van Graad 1-leerders en die onderrig van daardie leerders in Engels hersien en ter syde gestel word. Die saak het in Februarie 2005 in die Kaap van Goeie Hoop Provinsiale Afdeling voor regter Thring gedien (Governing Body of Mikro Primary School and another v Western Cape Minister of Education and others [2005] 2 AII SA 37(C)).

Toe die uitspraak ten gunste van die Laerskool Mikro was en bevind is dat die Departement onregmatig opgetree het deur die betrokke skool te dwing om 21 Engelssprekende Graad 1leerders in Engels te onderrig, is appèl aangeteken, 'n saak wat in Mei 2005 voor regter Streicher, bygestaan deur regters Cameron, Brand, Lewis, en Mlambo, gedien het (The Supreme Court of Appeal of South Africa, case no: 140/05; ook [2005] JOL 14774 (SCA)). Toe ook hierdie hof die uitspraak van die Kaapse Hooggeregshof bevestig, het die Onderwysdepartement aangedui dat hulle hul op die Konstitusionele Hof gaan beroep, 'n besluit waarvan later afgesien is (Rapport 2005-03-13, Volksblad 2005-03-17, Volksblad 2005-06-28).

Die derde voorbeeld waarna verwys word om die amptelike druk op Afrikaans-mediumskole aan te toon, het in die Noord-Kaap afgespeel. Op 31 Augustus 2004 het die Lid van die Uitvoerende Raad van Onderwys aangekondig dat alle enkelmediumskole in die Kurumandistrik, naamlik Seodin Primêre Skool, Kalahari Sekondêre Skool, Kuruman Primêre 
Skool, Wrenchville Primêre Skool, Wrenchville Sekondêre Skool, asook die Noord-Kaapse Landbouskool, vanaf Januarie 2005 na dubbelmedium- Afrikaans en Engels skole moet oorslaan.

Die volgende dag, 1 September 2004, het die hoof van die Onderwysdepartement aan die skole onder andere die volgende inligting verskaf:

I propose to admit the learners as follows:

(a) The learners presently in Grade 7 at Kuruman Primary School will be admitted to Grade 8 at Kalahari High School;

(b) The Grade 7 learners at Wrenchville Primary School will proceed to Wrenchville Secondary School;

(c) 200 learners will be transferred from Wrenchville Primary School to Seodin Primary School;

(d) 150 learners will be transferred from Wrenchville Primary School to Kuruman Primary School; and

(e) The Grade 10 to 12 at Bankhara-Bodulong will be transferred to Kalahari High School and Bankhara-Bodulong will no longer offer grades in the FET (Further Education and Training) phase of the curriculum; and

(f) All new Grade 1 applicants will be distributed equitably among the primary schools.

You are called upon to comment on these proposals by 8 September 2004.

The public will be informed immediately of the MEC's decision and the procedure outlined above. They will also be encouraged to start applying now to ensure that no time is lost in finalizing the admissions for next year.

I am looking forward to receiving your advices.

(Seodin Primary School and others v MEC of Education of the Northern Cape and others. Case nr 1177/2004, te 17)

Soos in die geval van Primêre Skool Middelburg en Laerskool Mikro het Seodin Primêre Skool, Kalahari Hoërskool, en die Noord-Kaapse Landbouskool hulle tot die hof gewend. Die saak het in Mei 2005 in die Noord-Kaapse Afdeling voor regter Kgomo gedien (Seodin Primary School and others v MEC of Education of the Northern Cape and others. Case nr 
1177/2004). Uitspraak is op 24 Oktober 2005 gelewer, waarin die drie skole se aansoek afgekeur is, hoofsaaklik op grond van die feit dat nie een van die drie skole 'n goedgekeurde taalbeleid gehad het soos bepaal in art. 6(2) van die Skolewet no. 84 van 1996 nie.

Dit het later uitgekom dat nie een van die 431 openbare skole in Noord-Kaap 'n goedgekeurde taalbeleid het nie (Volksblad 2005-11-05). Op 'n vergadering van die portefeuljekomitee vir onderwys het Carel Boshoff IV gesê dat so 'n toestand wys op die Departement se gebrek aan geesdrif om skole hiermee by te staan, en gewonder of die Departement "sy eie skole nie subtiel ondermyn om hulle meer kwesbaar te maak vir departementele manipulasie van toegang en taalbeleid nie" (Volksblad 2005-11-05).

Wat al drie sake aantoon, soos Rossouw (2005:8) oor die Mikro-geval opmerk, is "dat die huidige regering toenemend arrogant met sy mag begin omgaan en al hoe onversetliker in sy rasgedrewe transformasieprojek raak", aspekte wat deur van die howe gekommentarieer is:

[Die respondente het] bestaande administratiewe voorskrifte verontagsaam wat onder andere daargestel is ter beskerming van taal- en kultuurbelange wat vir baie mense kosbaar is. Hulle het die onderhawige aansoek met mag en mening bestry, al moes hulle $a b$ initio geweet het dat hul administratiewe optrede verkeerd was. Die houding wat die respondente inneem, gaan nie net mank aan 'n erkenning van die applikante se regte nie, maar ook aan respek vir die applikante se menings, aan eerbied vir die applikante se verknogtheid aan hulle eie taal en kultuur en verontagsaam die belange van die individuele leerders wat deur die respondente by hierdie proses betrek is. (Laerskool Middelburg en ander v Departementshoof: Mpumalanga Departement van Onderwys en andere [2002] 4 AII SA 745(T) te 756)

Ook elders in sy uitspraak verwys regter Bertelsmann na die ideologiese gedrewenheid van die respondente:

Uit die houding wil dit voorkom asof die respondente in beginsel besluit het om met Afrikaans-enkelmediumskole in Mpumalanga weg te doen, ten spyte van die bepalings van artikel 29(2) van die Grondwet en van die Nasionale Taalbeleid. Die optrede word klaarblyklik nie net deur die eise van praktiese noodsaak gemotiveer nie, maar in 'n 
veel groter mate deur die beginsel dat sodanige skole getransformeer moet word. Ek het hierdie punt tydens betoog by herhaling aan mnr. Dreyer SC [vir die Respondente] genoem: Dit was uiteindelik gemeensaak dat dit die benadering van die respondente is. (Laerskool Middelburg en ander v Departementshoof, Departement van Onderwys en andere [2002] 4 AII SA 745 (T) te 754)

Die verontagsaming en eie interpretasie van bepalings van die Suid-Afrikaanse Skolewet 84 van 1996 en verbandhoudende regulasies laat blyk hoe die Departement en sy amptenare alle middele aangewend het in hulle poging om die Primêre Skool Middelburg in 'n parallelmediuminstelling om te skakel.

Norme en standaarde met betrekking tot taalbeleid van skole bepaal dat dit eers redelikerwys prakties uitvoerbaar is om onderwys in 'n bepaalde onderrigtaal te voorsien as ten minste 40 leerders in grade 1 tot 6 in 'n bepaalde graad dit in 'n bepaalde skool versoek, en verder dat 'n laerskool as vol beskou word wanneer die verhouding van 40 leerders tot 1 onderwyser in 'n gegewe graad in 'n gegewe klas bereik word (Staatskoerant no 18546, 1997-12-19).

Die applikante in hierdie geval lê die regulasie uit dat 'n enkelmediumskool slegs dán verplig kan word om 'n tweede baan te open wanneer al die ander skole in 'n skooldistrik wat die betrokke taal kan aanbied, in die betrokke graad die verhouding van 40 leerders tot 1 onderwyser bereik het en daar 40 leerders aansoek doen om tot die eerste applikant toegelaat te word.

Daarteenoor betoog die respondente dat dit die Departementshoof vrystaan om van 'n Afrikaans-mediumskool te verwag om 'n Engelse baan te open selfs voordat die vereiste getalleverhouding van 40 tot 1 in ander skole wat Engels as voertaal gebruik, bereik is, en selfs al is daar minder as 40 leerders vir die voorgestelde nuwe graad in die nuwe baan by die applikant.

So 'n uitleg strook hoegenaamd nie met die uitdruklike bewoording van die regulasie nie. Buitendien kon die drie ander skole in die skooldistrik aan die begin van die skooljaar verdere leerders wat onderrig in Engels verlang het, opgeneem het. Die hof het dan ook die uitleg wat die respondente aan die regulasie wou verleen as 'n "onhoudbare teenstrydige uitleg" beskryf 
(Laerskool Middelburg en ander v Departementshoof, Departement van Onderwys en andere [2002] 4 All SA 745 (T) te 750).

Onder andere die sterk moontlikheid dat (i) die Departement hulle nie by die besluit sou neerlê indien uitspraak ten gunste van die skool was nie, en (ii) die belange van die leerderswat die Hof as van deurslaggewende belang geag het - daardeur benadeel sou word, het die hof "genoop" om die aansoek van die hand te wys:

Dit is duidelik dat die eerste en tweede respondente reeds sedert 1996, met klaarblyklike verontagsaming van die administratiewe voorskrifte, poog om die eerste applikant tot 'n parallelmediumskool te omskep. Mnr. Dreyer het toegegee dat dit hoogs waarskynlik is dat die eerste en tweede respondente hierdie poging sal hervat indien die onderhawige aansoek sou slaag. Dit is in niemand se belang om die applikante en die leerders aan 'n herhaling van die proses bloot te stel nie. (Laerskool Middelburg en 'n ander $v$ Departementshoof: Mpumalanga Departement van Onderwys en andere [2002] 4 AII SA 745(T) te 756)

Sodoende het die reg op moedertaalonderrig in 'n enkelmediumskool letterlik die slagoffer van onregmatige optrede deur amptenare geword.

In die Mikro-saak is die belange van die leerders indien hulle na 'n ander skool verskuif, ook beredeneer, maar in hierdie geval het die hof beslis dat daar nóg 'n belangriker aspek is wat in aanmerking geneem moet word, naamlik gehoorsaming van die wet deur die staat:

That [the value of legality] is a principle which is so fundamental and so important in any civilised country that it must be only extremely rarely, if ever, that the rule of law can be "held hostage", as Mr Osborne [for the applicant] puts it, to the best interests of children. Indeed, it is difficult to imagine how it could ever be in the best interests of children, in the long term, to grow up in a country where the State and its organs and functionaries have been elevated to a position where they can regard themselves as being above the law, because the rule of law has been abrogated as far as they are concerned. It could be cogently argued, I think, that a court which, by its orders, exposed children to the risk of growing up in such a place would be doing them a 
greater disservice than a court which merely ordered that they be removed from one school and placed in another, equally acceptable to their parents, and only a short distance away. (Governing Body of Mikro Primary School and another v Western Cape Minister of Education and others [2002] 2 AII SA 37(C) te 56)

Voorbeelde van "onwettige" optrede deur die amptenare van die Departement is onder andere die aandrang van die amptenare dat die 21 leerders en hul ouers die openingseremonie op 19 Januarie 2005 in die skoolsaal moet bywoon, 'n daad wat die hof as "interference ... in the government and professional management of the school" (p. 54) beskryf het.

'n Tweede voorbeeld deur die hof ge-opper om aan te toon hoe die betrokke amptenare onaanvaarbaar opgetree het, is die beëdigde verklaring waarin beweer is dat enkele tydelike klaskamers in 'n nabygeleë skool wat as moontlikheid genoem is om vir die 21 leerders voorsiening te maak "were erected prior to 1971, are in a dilapidated state and pose a serious safety hazard" (p. 57). Die enigste alternatiewe tydelike plasingsmoontlikheid, het die beëdigde verklaring voortgegaan, is "a school used for severely mentally handicapped learners" (p. 57). Die inligting oor die klaskamers het geblyk vals te wees, en die dreigement oor die alternatiewe skool vir verstandelik gestremde leerders laakbaar:

I regard this unfounded threat to the well-being of six-year old children as highly reprehensible. It seems to me that the first and second respondents, having imposed their will on the unwilling school, and having achieved a fait accompli by engineering the children's attendance there, were prepared to use this dreadful threat as a lever to ensure that their wishes were not thereafter thwarted. In my view the first and second respondents must bear a heavy burden of public opprobrium for their conduct. (Governing Body of Mikro Primary School and another $v$ Western Cape Minister of Education and others [2005] 2 AII SA 37 (C) te 58-59)

In die volgende afdeling sal die aandrang van veral Afrikaanssprekers op moedertaalonderrig in enkelmediuminrigtings en die eis van veral die opkomende swart middelklas dat alle inrigtings wat deur die staat befonds word, toegang aan leerlinge in die taal van hul keuse (lees: Engels) moet bied, in die lig van die Grondwet en betrokke wette beoordeel word. 


\section{Reg op moedertaalonderrig in enkelmediuminrigtings versus reg tot toegang in taal van keuse}

Die Grondwet van die Republiek van Suid-Afrika (Wet no 108 van 1996) spreek in die aanhef die oortuiging uit dat Suid-Afrika "behoort aan almal wat daarin woon, verenig in ons verskeidenheid", en erken in art. 30 dat elkeen die reg het om die taal van eie keuse te gebruik en om aan die kulturele lewe van eie keuse deel te neem, natuurlik met die proviso dat dit nie gedoen moet word op 'n wyse wat met enige bepaling in die Handves van Regte onbestaanbaar is nie.

Om uitvoering aan hierdie voorsienings te gee, word in art. 6 in drie onderskeie dele algemene bepalinge betreffende taalregte gegee. Art. 6(1) bepaal 11 tale as amptelik, art. 6(2) en 6(4) bevat normatiewe riglyne vir taalbeleid, terwyl art. 6(3)(a) en (b) 'n aantal praktiese oorwegings (of faktore) noem wat in berekening geneem moet word in die keuse van ' $\mathrm{n}$ taal of tale vir amptelike gebruik in 'n spesifieke geval. 'n Duidelike aanwysing hoe die drie dele verband hou, en die balans tussen die relatiewe gewig wat aan die bevordering van amptelike veeltaligheid aan die een kant, en kompeterende oorwegings aan praktiese aangeleenthede (soos taalvoorkeure) aan die ander kant, gegee moet word, ontbreek. Die inherente dubbelsinnigheid van art. 6, volgens Du Plessis en Pretorius (2000:507), dra by tot die inkonsekwente toepassing van die bepalings.

Die normatiewe riglyn in art. 6(4) om alle tale billik ("equitably") te behandel, is 'n breuk met die verlede waar die norm vir Afrikaans en Engels gelykheid ("equality") was:

Equitable treatment is treatment that is just and fair in the circumstances. Those circumstances include a history of official denigration and neglect of indigenous languages. Equity may therefore require that the languages that FCs 6(2) terms historically diminished in use and status receive particular attention and support from the state. (Currie 1998:37.5)

Die nosie 'gelykheid van aansien' ("parity of esteem") voorsien dat elke amptelike taal die status van 'n gereelde en sigbare medium van amptelike kommunikasie sal bereik, en verbied sowel taaldominasie en hiërargisering as amptelike eentaligheid (Currie 1998:37.6, Du Plessis en Pretorius 2000:520). 
Naas die nosie 'billike behandeling' van die amptelike tale soos in art. 6(4) van die Grondwet behandel, kom in art. 9 van hoofstuk 2, Handves van Regte, 'gelykheid' aan die bod. Na 'n lang geskiedenis van diskriminasie en ongelykhede van die verlede kon dit voorsien word dat die nuwe Grondwet spesifiek die kwessie van gelykheid sou aanspreek. Spesifiek art. 9(3) verwys na taal en kultuur:

Die staat mag nie regstreeks of onregstreeks onbillik teen iemand diskrimineer op een of meer gronde nie, met inbegrip van ras, geslagtelikheid, geslag, swangerskap, huwelikstaat, etniese of sosiale herkoms, kleur, seksuele georiënteerdheid, ouderdom, gestremdheid, godsdiens, gewete, oortuiging, kultuur, taal en geboorte.

Dit bring ons by art. 29 wat oor onderwys handel, en wat van besondere belang is in 'n bespreking van gelyke onderwysgeleenthede. Hierdie artikel was een van die laaste struikelblokke wat in die onderhandelingsproses oorkom moes word, en dit het byna die onderhandelinge verongeluk. Dit is letterlik op die laaste minuut gefinaliseer (Malherbe 1997:91-95, Ebrahim 1998:215-216, Heugh 2002:462, Malherbe 2004:12, 20). Die ANC het 'n onderwyssisteem voorgestaan wat gelyke en nie-rassige geleenthede vir almal skep, en wat die ongelykhede van die verlede sou uitwis. Aan die ander kant wou van die ander partye die bestaande afsonderlike skole vir die onderskeie taalgroepe beskerm deur vir 'n grondwetlike reg op enkelmediumskole te beding.

Om nie die onderhandelingsproses te kelder nie, is 'n kompromis bereik. Soos met elke kompromis, het dit nie die heelhartige steun van alle betrokke partye geniet nie, 'n houding wat nog steeds geld. Art. 29(1) erken die reg van elke individu op sowel basiese as verdere onderwys, terwyl art. 29(2), wat die eintlike kompromis was, die taalaspek behandel:

Elkeen het die reg om in openbare onderwysinstellings onderwys te ontvang in die amptelike taal of tale van eie keuse waar daardie onderwys redelikerwys doenlik is. Ten einde doeltreffende toegang tot en verwesenliking van hierdie reg te verseker, moet die staat alle redelike alternatiewe in die onderwys, met inbegrip van enkelmediuminstellings, oorweeg, met inagneming van -

(a) billikheid; 
(b) doenlikheid; en

(c) die behoefte om die gevolge van wette en praktyke van die verlede wat op grond van ras gediskrimineer het, reg te stel.

Die reg om in 'n amptelike taal of tale "van eie keuse" onderrig te ontvang, word erken, dog onderrig in enkelmedium- opvoedkundige inrigtings is nie 'n grondwetlike reg nie. Enkelmediumskole word egter uitgesonder as een van die alternatiewe wat oorweeg kan word om doeltreffende toegang te verseker tot onderrig in die amptelike taal van eie keuse.

Soos in ' $n$ vorige afdeling aangetoon, is die voordele van moedertaalonderrig van 'n opvoedkundige, kognitiewe, sosiale, en psigologiese aard. Wat die opvoedkundige voordele betref, wys Malherbe (2004) op 'n aspek wat nog nie genoegsaam aandag ontvang het nie, naamlik

that the right to education in one's preferred language is also particularly relevant for the achievement of equal educational opportunities. It may, in other words, be argued that the right is yet another instrument through which equal educational opportunities should be pursued. (Malherbe 2004:20)

In Laerskool Middelburg en ' $n$ ander v Departementshoof: Mpumalanga Departement van Onderwys en andere [2002] 4 All SA 745 (T) bespreek die Hof die inhoud van die reg op 'n enkelmediumskool teenoor die reg om in 'n amptelike taal van keuse onderrig te word (te 751 e.v.). Die laasgenoemde reg is die kernreg op moedertaalonderrig. Die aanspraak op 'n instelling waarin enkelmediumonderrig in 'n openbare skool voorsien word, is in wese 'n aanspraak op emosionele, kulturele, religieuse, en maatskaplik-sielkundige geborgenheid in eie kring. Behoorlik bedryf, kan 'n parallelmediumskool ook voldoen aan die aanspraak van elke kultuurgemeenskap op onderrig in sy eie amptelike taal of die taal van voorkeur. Slegs indien daar 'n duidelik bewese behoefte bestaan om onderwysfasiliteite met ander kultuurgroepe te deel is die reg op enkelmedium- openbare onderwysinstellings ondergeskik aan die reg wat elke Suid-Afrikaner op onderwys het, wat nie beteken dat 'n bestaande enkelmediuminstelling "goedsmoeds en sonder nakoming van bestaande voorskrifte aangetas kan word nie" (te 751). 
Ook in Governing Body of Mikro Primary School and another v Western Cape Minister of Education and others [2005] 2 All SA 37 (C) (te 48 e.v.) word die meriete van enkelmediuminrigtings aangespreek. Oorskakeling na 'n parallelmediuminrigting "must inevitably have a profound influence on the modus vivendi, the customs, traditions and almost every aspect of the atmosphere which pervades the school" (te 48).

In die Appèlaansoek wat die Wes-Kaapse minister van Onderwys teen die uitspraak in die bogenoemde saak aangeteken het, het die hof uitvoerig kommentaar gelewer op die skynbaar botsende belange van die reg op moedertaalonderrig in enkelmediuminrigtings en die reg tot toegang in taal van keuse (The Supreme Court of Appeal of South Africa. Case no 140/05 te 20 e.v.).

Die Wes-Kaapse onderwysowerhede het art. 29(2) geïnterpreteer dat élkeen die reg het tot onderrig in die amptelike taal van keuse by elke ("each and every") openbare onderwysinstelling waar daardie onderwys redelikerwys doenlik is. Indien dit die korrekte interpretasie is, sou dì beteken dat 'n groep Afrikaanssprekende leerlinge geregtig sou wees om in Afrikaans by 'n Engels-mediumskool direk in die omgewing van 'n Afrikaansmediumskool onderrig te ontvang mits daar openinge is en hulle sou kon aantoon dat dit redelikerwys doenlik is om onderrig in Afrikaans by daardie skool te verskaf. Omdat die reg tot onderrig "elkeen" insluit, sou so 'n interpretasie meebring dat seuns 'n grondwetlike reg het om onderrig te word by 'n meisieskool indien redelikerwys doenlik.

Die hof verwerp derhalwe die Wes-Kaapse onderwysowerhede se interpretasie van art. 29(2). Die reg van elkeen om in 'n openbare onderwysinstelling onderwys te ontvang in die amptelike taal of tale van eie keuse waar daardie onderwys redelikerwys doenlik is, is 'n reg teen die Staat, met 'n verwysing na art. 7(2) van die Grondwet: Die Staat moet die regte in die Handves van Regte eerbiedig, beskerm, bevorder, en verwesenlik.

Die Grondwet erken die moontlikheid van redelike alternatiewe om die reg om onderwys te ontvang, te verseker. Die Staat moet al hierdie alternatiewe, insluitende enkelmediuminrigtings, oorweeg. Vir die Hof is dit 'n duidelike aanwysing dat in terme van art. 29(2) elkeen die reg het om onderrig te word in 'n amptelike taal van eie keuse in 'n openbare onderwysinstelling wat deur die Staat voorsien word en indien redelikerwys 
doenlik, maar nie 'n reg om by elke openbare onderwysinstelling onderrig te word slegs indien dit redelikerwys doenlik is nie. Die 40 leerders waarvan sprake is, het dus 'n grondwetlike reg om onderrig te ontvang in Engels in 'n openbare instelling wat deur die Staat voorsien word indien redelikerwys doenlik. Al was dit ook redelikerwys doenlik om opleiding in Engels by Mikro Primêre Skool te voorsien, het hulle nie 'n grondwetlike reg om daar onderrig in Engels te ontvang nie.

In die Noord-Kaapse geval (Saak no 1177/2004) het die Hof van die standpunt uitgegaan dat, omdat daar by elk van die skole meer as 40 leerlinge is wat onderrig in Engels verkies, hulle 'n grondwetlike reg het om dit wel te ontvang:

Although these learners did not initially have a constitutional right to receive their Education in English ... it has become immaterial as they now have a legitimate expectation to remain at these schools. (par. 54 te 52)

Ook verderaf (par. 56 te 53) word dit gestel dat die leerders 'n "vested right" verkry het en nie verwyder kan word sonder 'n hofbevel nie. In dieselfde paragraaf word die twee skynbaar botsende belange bespreek, naamlik om onderrig in 'n taal van keuse te ontvang, en om onderwys tot 'n sekere vlak te ontvang. In so 'n geval moet die twee belange teen mekaar opgeweeg word. In hierdie proses moet die oorwegings onder andere insluit die bydrae wat die reg lewer tot 'n oop en demokratiese gemeenskap gebaseer op vryheid en gelykheid (te 54), met ander woorde sonder enige verwysing na die grondwetlike waarde van menswaardigheid.

Naas die grondwetlike waardes van billikheid en gelykheid in die opvoedkunde kan twee verdere grondwetlike waardes onderskei word, naamlik menswaardigheid en vryheid. Art. 7(1) van die Handves van Regte lui:

Hierdie Handves van Regte is 'n hoeksteen van die demokrasie in Suid-Afrika. Dit verskans die regte van alle mense in ons land en bevestig die demokratiese waardes van menswaardigheid, gelykheid en vryheid. 
Reeds in hoofstuk I van die Grondwet wat die grondliggende waardes van die Republiek bevat, word daar verwys na "menswaardigheid, die bereiking van gelykheid en die uitbou van menseregte en vryhede" (art. 1(a)). Die Grondwet se klemlegging op gelykheid moet nie in isolasie beoordeel word nie, maar in die konteks van dieselfde beklemtoning van menswaardigheid en vryheid van die individu en die diversiteit van die gemeenskap. Dit is waarom "gelykheid" nie sinoniem is met "uniformiteit" nie, maar wel met "van gelyke waarde". Elkeen moet toegelaat word om hulself te wees sodat elke persoon se menswaardigheid en gelyke waarde gerespekteer en gehandhaaf word. Die Kanadese Appèlhof het bevind: "Human dignity means that an individual or group feels self-respect and self-worth" (Law v Canada (Minister of Employment and Immigration) 1 SCR 497 (1999) par.53, soos aangehaal deur Malherbe 2004:12 n.9). Daarom dat Malherbe (2004:12) verklaar:

The quest for equal educational opportunities is therefore as much a challenge to balance and harmonise the values of dignity, equality and freedom, to respect and accomodate people's 'otherness', and to build the South African nation on and not separately from its diversity.

\section{Slot}

Nie net die aanhef tot die Grondwet nie, maar ook die aanhef tot die Skolewet, laat hom positief uit oor die verskeidenheid van kulture en tale binne die landsgrense. Onder andere as gevolg van 'n sterk onderskrywing en propgagering van 'n ideologiese standpunt, naamlik homogenisme, word die begrip 'nasiebou' deur die bewindhebbers met eenheid vereenselwig en eenheid in verskeidenheid as 'n contradictio in terminus beskou. Die houding kom enersyds tot uitdrukking in die onderwysbeleid waar toelating ten koste van die Afrikaanssprekende se reg op enkelmediuminstellings verabsoluteer word, en andersyds deur die verwaarlosing van die inheemse tale in die onderwys. Taalregte wat deur die Grondwet gewaarborg word, word deur amptelike optredes wat toegang as belangrikste/enigste maatstaf verhef, geskend. Die gevaar is wesentlik dat deur die verandering van praktyke geleidelik nuwe inhoud aan die Grondwet gegee kan word, waardeur

the values of human dignity and freedom being sacrificed for the sake of a view which equals equality to uniformity, instead of the three values being applied in harmony to enhance the equal worth of people. (Malherbe 2004:22) 
Gebeur dit dat dusdanige nuwe inhoud aan die Grondwet gegee word, sal 'n beroep op die regbank nie noodwendig Afrikaanssprekendes se reg op enkelmediuminstellings erken nie, want, soos Koos Malan (medeprofessor in regte aan die Universiteit van Pretoria) betoog, is die regbank in laaste instansie 'n vertakking van dieselfde magselite wat in die wetgewer en die uitvoerende gesag die botoon voer (Malan 2006:14), of soos Giliomee (2005:277) dit stel: Die regering is "in belangrike opsigte die arbiter van die Grondwet". In hierdie verband kan Robert Dahl, deurlugtige Amerikaanse politieke wetenskaplike, se opmerking oor die Amerikaanse Hooggeregshof ook op Suid-Afrika van toepassing gemaak word:

Except for short-lived transitional periods when the old alliance is disintegrating and the new one is struggling to take control of political institutions, the Supreme Court is inevitably a part of the dominant national alliance. As an element of the political leadership of die dominant alliance, the court of course supports the major policies of the alliance. (soos aangehaal deur Malan 2006:14)

\section{Verwysings}

Bamgbose, Ayo. 2000. Language and exclusion. Hamburg: Lit Verlag.

Bloch, C. 2002. A case study of Xhosa and English biliteracy in the foundation phase versus English as a 'medium of destruction'. Perspectives in Education 20(1): 65-78.

Blommaert, J. and J. Verschueren. 1998. The role of language in European nationalist ideologies. In B.B. Schieffelin, K.A. Woolard, A. Kathryn, and P.V. Kroskrity (eds). Language ideology and theory. New York: Oxford University Press. pp. 189-210.

Cobarrubias, J. 1983. Ethical issues in status planning. In J. Cobarrubias and J.A. Fishman (eds). Progress in language planning. New York: Mouton. pp. 41-86.

Cummins, J. 1989. Language and literacy acquisition in bilingual context. Journal of Multilingual and Multicultural Development 10(1): 17-31.

Currie, I. 1998. Official languages. In M. Chaskalson, J. Kentridge, and J. Klaaren (eds). Constitutional law in South Africa. Cape Town: Juta. pp. 37-1 - 37-15. 
Desai, Z. 2003. Language-in-education policy in practice: A case study of a primary school in Khayelitsha Cape Town. In P. Cuvelier, T. Du Plessis, and L. Teck (eds). Multilingualism, education and social integration. Pretoria: Van Schaik. pp. 141-162.

Du Plessis, L.T. and J.L Pretorius. 2000. The structure of the official language clause. A framework for its implementation. South African Public Law 15: 505-526.

Ebrahim, H. 1998. The soul of a nation: Constitution-making in South Africa. Cape Town: Oxford University Press.

Giliomee, H. 2005. 'n Algemeen geldende basis vir Afrikaans? Tydskrif vir Geesteswetenskappe 45(2): 276-282.

Heugh, K. 2000. The case against bilingual and multilingual education in South Africa. Cape Town: PREASA. [An edited version appeared in Perspectives in education 20(1): 171196, in 2002.]

Heugh, K. 2002. Recovering multilingualism: Recent language-policy developments. In R. Mesthrie (ed). Language in South Africa. Cambridge: Cambridge University Press. pp. 449-475.

Heugh, K. 2003. Rehabilitating mother-tongue and bilingual education - the role of civil society. In P. Cuvelier, T. Du Plessis, and L. Teck (eds). Multilingualism, education and social integration. Pretoria: Van Schaik. pp. 120-130.

Kamwangamalu, N.M. 2004. The language planning situation in South Africa. In R.B. Baldauf and R.B. Kaplan (eds). Language planning and policy in Africa. Volume I. Clevedon: Multilingual Matters. pp. 197-281.

Makoni, S. 1997. Linguistic imperialism: Old wine in new bottles. SAALA Newsletter (June): 13-15.

Makoni, S. 2003. From misinvention to disinvention of language: Multilingualism and the South African Constitution. In S. Makoni, G. Smitherman, A.F. Ball, and A.K. Spears (eds). Black linguistics. London: Routledge. pp. 132-151.

Malan, K. 2006. Die regbank: Hoe onafhanklik en doeltreffend? Die Vrye Afrikaan, 21 Julie 2006: 14.

Malherbe, E.F.J. 1997. Reflections on the background and contents of the education clause in the South African bill of rights. Tydskrif vir die Suid-Afrikaanse reg [Journal of South African law] 1997(1): 85-99.

Malherbe, R. 2004. The constitutional framework for pursuing equal opportunities in education. Perspectives in Education 22(3): 9-28. 
Murray, S. 2002. Language issues in South African education: An overview. In R. Mesthrie (ed). Language in South Africa. Cambridge: Cambridge University Press. pp. 434-448.

Pattanayak, D.P. 1988. Monolingual myopia and the petals of the Indian lotus: Do many languages divide or unite a nation? In T. Skutnabb-Kangas and J. Cummins (eds). Minority education: From shame to struggle. Clevedon: Multilingual Matters. pp. 379390.

Perry, T. 2004. Language rights, ethnic politics - A critique of the Pan South African Language Board. Cape Town: Project for the Study of Alternative Education in South Africa.

Phillipson, R. 1992. Linguistic imperialism. Oxford: Oxford University Press.

Plüddemann, P. 2002. Action and reflection: Dual-medium primary schooling as language policy realisation. Perspectives in Education 20(1): 47-64.

Rapport 2005-03-13.

Reagan, T.G. 2002. Language planning and language policy: Past, present and future. In R. Mesthrie (ed). Language in South Africa. Cambridge: Cambridge University Press. pp. 419-433.

Rossouw, J. 2005. Onderwys: Die staat teen die gemeenskap - Die geval van Laerskool Mikro. Die Vrye Afrikaan 2(6): 8-12.

Ruiz, R. 1988. Orientations in language planning. In S. McKay and S.C. Wong (eds). Language diversity - Problem or resource. Cambridge: Cambridge University Press. pp. 3-25.

Skutnabb-Kangas. T. 2000. Linguistic genocide in education - or worldwide diversity and human rights? Mahwah, N.J.: Lawrence Erlbaum Associates.

Spolsky, B. (ed.). 1986. Language and education in multilingual settings. Clevedon: Multilingual Matters.

Staatskoerant 18546, 1997-12-19.

Van Zyl, J. 2003. Afrikaanse skole sê les op. Finansies en Tegniek 7 Maart 2003.

Volksblad 2005-03-17, 2005-06-28, 2005-11-05.

Webb, V. 2006. Perspektiewe op moedertaalonderrig. Tydskrif vir Geesteswetenskappe 46(2): 37-50. 


\section{Litigasie}

Governing Body of Mikro Primary School and another v Western Cape Minister of Education and others [2005] 2 ALL SA 37(C).

Laerskool Middelburg en 'n ander v Departementshoof: Mpumalanga Departement van Onderwys en andere [2002] 4 ALL SA 745 (T).

Seodin Primary School and others v MEC of Education of the Northern Cape and others, Case nr 1177/2004.

The Supreme Court of Appeal of South Africa. Case No. 140/05. (Ook [2005] JOL 14774 (SCA)).

\section{Wette}

Bantoe-onderwyswet (Wet No. 47 van 1953) en Amendement (Wet No. 90 van 1979).

Grondwet van die Republiek van Suid-Afrika (Wet No. 108 van 1996).

Suid-Afrikaanse Skoolwet (Wet No. 84 van 1996). 